\title{
Common Foreign and Security Policy After Brexit
}

\author{
Maria José Rangel de Mesquita
}

\section{Abstract}

Within the wider context and scope of CFSP the EU Global Strategy and some subsequent developments on CSDP may be relevant to the shaping of the future EU-UK relationship after Brexit raising the question of what could be the status of the UK regarding participation in CFSP: a mere third State or ex-EU third State. Different forms of future cooperation have been envisaged in several initiatives, both from the EU and the UK side, addressing the issue of CFSP and CSDP after Brexit. The contents of both the texts of the Withdrawal Agreement and of the Political Declaration of 25 November 2018 regarding the area of CFSP/ CSDP may indicate that the future EU-UK relationship in this area, on one hand is rather programmatic and modest and that the concrete terms of the participation are rather narrow and still need to be detailed (in future agreements) and that no specific ex-EU Member State statute is envisaged; and, on the other hand, that some of the concrete areas in which closer cooperation is envisaged (in particular PESCO and defence capabilities development) relate to the sub-area of CSDP. However, the guidelines laid down in both texts appear to still leave room to shape a differentiated third State status in the field of CFSP/CSDP. Even in areas where the status of third State is clearly mentioned - PESCO and EU missions and operations - neither the rules of third States participation are definitively defined nor is the envisaged Framework Participation Agreement necessarily bound to follow a single model. The next step - negotiating and agreeing on more detailed rules - appears to be an opportunity to envisage the features of a possible differentiated third State status in the field of CFSP/CSDP.

\section{Introductory remarks: External Action, Global Strategy and beyond}

A. The wider context: EU External Action and CFSP and CSDP within the CFSP

Addressing the issue of the future of European Union (EU) Common Foreign and Security Policy (CFSP) after Brexit requires two previous remarks 
regarding its context - the EU External Action as the wider (area of competences) context of CFSP - and its scope - the CFSP itself including the subarea of competences regarding specifically the Common Security and Defence Policy (CSDP). And this is so for two main reasons: firstly, whatever the model of the future relations between the EU and the United Kingdom (UK) within and beyond the framework of the withdrawal agreement may be in the specific area of CFSP, it cannot exclude the overall framework and approach in the field of EU External Action, including CFSP, laid down in the Global Strategy for the EU's Foreign and Security Policy (EU Global Strategy) and the subsequent developments; secondly, within the (largest) CFSP the CSDP raises particular issues regarding the future possible cooperation between the EU and UK, especially regarding participation in EU CFSP instruments and international (either regional or universal) organizations in the field of international security and defence involving military capacities, in particular NATO. ${ }^{1}$

Within the wider context and scope of CFSP the EU Global Strategy and some subsequent developments may be particularly relevant to the shaping of the future EU-UK relationship (see B. below), raising the question of what could be the status of the UK regarding participation in CFSP: a mere third State or ex-EU third State. The text will further address initiatives regarding CFSP and CSDP after Brexit, both in the EU and UK perspective (see II. below), as well as the final text of the Withdrawal Agreement and the Political Declaration of 25 November 2018 (see III. below) and the way they envisage the future EU-UK relationship in the field of CFSP and CSDP - and whether they admit or, at least, do not exclude the participation of the UK in CFSP and CSDP and respective initiatives with a status that may differ from the status of the third States that have already been allowed to cooperate with the EU in that field of CFSP and CSDP. Finally, the text will focus on the issue of shaping a possible differentiated third State status in the field of CFSP and CSDP (see IV. below).

1 The text corresponds essentially to the intervention in the European Constitutional Law Network, Lisbon Workshop 23-24 June 2017, Brexit-Challenge or end of EU constitutional law? The future of EU policies after Brexit although some subsequent developments have been further considered in the text. In order to avoid overlapping with other External Action-related topics addressed in the Conference, the text focuses mainly on CFSP (as a significant part of External Action), including the CSDP and does not address as well the issue of the consequences of a UK break out on the possible design of the relationship with the EU (see T Oliver, 'What if the UK were to break up? A closer look at an English Foreign policy', available at www.blogs.lse.ac.uk/brexit/2017/06/09/english-foreign-policy-what-if-the-uk-were-t o-break-up/). 


\section{B. The Global Strategy for the EU's Foreign and Security Policy and follow-up: trends on the EU side}

The presentation of the Global Strategy for the EU's Foreign and Security Policy (EU Global Strategy) ${ }^{2}$ by the High Representative of the Union for Foreign Affairs and Security Policy intends to establish a new (although ambitious) overall framework and approach - a political vision - in the field of EU External Action, including CFSP and establish the EU priorities in this respect.

The EU Global Strategy assumed that present times are times of «existential crisis, within and beyond the EU» and that the European project is being questioned in many ways, thus proposing a «stronger Europe» - that EU citizens deserve and the wider world expects - based on shared interests (and values) and oriented by clear principles (and principled pragmatism) and focused to pursue five clear priorities - the security of the Union; promoting State and Societal Resilience to EU East and South; developing an integrated approach to conflicts and crisis; promoting and supporting cooperative regional orders; and, finally, reinforcing global governance for the $21^{\text {st }}$ Century, based on International law, including the principles of the UN and the Helsinki Final $\mathrm{Act}^{3}$ - which are related to the macro-area of competences of the EU External Action as such, as foreseen by the Treaty of Lisbon. ${ }^{4}$ The intention to assume the responsibility of the EU as a global stakeholder, as the Treaty of Lisbon announced, is envisaged by the EU Global Strategy as a shared responsibility meaning being engaged with other players and partnerships in a connected (networked) world. Moreover, and concerning the priorities established in the EU Global Strategy, three features must be underlined: first, regarding promoting security of the Union (in the fields of defence, cyber, counter terrorism, energy and strategic communications) the idea of an «appropriate level of ambition and strategic autonomy» is announced - possibly (also) meaning a shift of strategy to the further development of an own EU defence policy; second, the idea of promoting resilience (of States and societies), both at east and south, within and beyond European neighbourhood policy, as a

2 Shared Vision, Common Action: a Stronger Europe. A Global Strategy for the European Union's Foreign and Security Policy (June 2016) - consulted as well as the other EU documents further mentioned in www.eeas.europa.eu.

3 See EU Global Strategy (2016), 3.1 to 3.5.

4 See also Conclusions on the Global Strategy for the External and Security Policy of the Union approved by the EU Foreign Affairs Council (FA Council), 17 October / 2016, CFSP/PESC 814, CSDP/PSDC 572. 
way to achieve transformation and attraction towards the EU- namely through the establishment of closer relations within the European Neighbourhood Policy (ENP) in order to spur transformation in neighbour (and also other) third countries and the targeting of the most acute cases of governmental, economic, societal and climate/energy fragility and the development of more effective migration policies for Europe and its partners; third, the clear aspiration, as a global player, to aim at transformation (rather than preservation) of the existing international order - mainly through striving for a strong UN as the bedrock of the multilateral rulesbased order and the development of global coordinated responses and also its commitment to global governance by the determination to reform the UN, including the Security Council. ${ }^{5}$

Two connections may be established between the EU Global Strategy and the future EU-UK relationship in the field of CFSP/CSDP: on one hand the timing of its presentation can be read (also) as a 'reaction' to the Brexit referendum (since the EU announces its political will to reinforce its role as a global player); on the other hand the translation of the EU «political vision» (as presented in the EU Global Strategy) into action has led to a significant development in the field of CFSP, mainly CSDP, through the adoption of three main categories of initiatives - political, institutional and financial - in some of which the UK may participate during and after the transition period.

In fact, the subsequent translation of the ,political vision' and the five broad priorities expressed in the EU Global Strategy into concrete initiatives and actions has led to the significant development of the CSDP, leading to the EU Security and Defence package» based on three pillars: ${ }^{6}$

i) a 'new level of ambition in security and defence' agreed within the Coun$\mathrm{cil}^{7}$ as new political goals and ambitions for Europeans to take more responsibility for their own security and defence;

ii) the European Defence Action Plan, ${ }^{8}$ aimed at facilitating and incentivising defence cooperation between Member States through the establish-

5 See EU Global Strategy (2016), 3.2 and 3.5.

6 See European Defence Action Plan, Introduction, 3.

7 Council Conclusions on implementing the EU Global Strategy in the Area of Security and Defence - (Foreign Affairs) Council Conclusions of 14 November 2016, especially Level of Ambition, 7, a., b. and c., and Actions, 11-18.

8 Communication from the Commission to the European Parliament, the European Council, the Council, the European Economic and Social Committee and the Committee of Regions - European Defence Action Plan (COM(2016)950 final of 30 November 2016). 
ment of a research and of a capability window and foreseeing new financial tools to help Member States and the European defence industry to develop defence capabilities, including the European Defence Fund (EDF);

iii) a set of concrete actions (as a follow up to the Warsaw EU-NATO Joint Declaration of 8 July $2016^{9}$ which identified seven key areas of cooperation $^{10}$ ) adopted in parallel by the Council of the EU and Foreign Ministers of NATO on 6 December $2016^{11}$ which foresees forty-two concrete proposals for implementing in the seven areas of cooperation.

Therefore, in the specific field of CFSP/CSDP and in the period 20162019, the three main categories of initiatives above mentioned were adopted by either sources of binding secondary law or soft law instruments: (i) political and strategic; (ii) institutional and operational; and (iii) financial initiatives.

Within the first category - political and strategic - several instruments were adopted by the EU. The above-mentioned Commission's European Defence Action Plan, contributes to ensuring that the European defence industrial base is able to meet Europe's current and future security needs and, in that respect, enhances the Union's strategic autonomy, strengthening its ability to act with partners. It focuses on capability needs and supports the European defence industry and is based on three main pillars launching a European Defence Fund, fostering investments in defence supply chains and reinforcement of the single market for defence - and aims also at maximising civil/military synergies across EU policies.

Afterwards, the Implementation Plan on Security and Defence ${ }^{12}$ sets out proposals to implement the EU Global Strategy in the area of security and defence and mainly it sets up the aims of the proposed «new Level of ambi-

9 Joint Declaration by the President of the European Council, the President of the European Commission and the Secretary General of the North Atlantic Treaty Organization of 8 July 2016 (see www.natolibguides.info).

10 Ibid. The seven key areas of cooperation identified are: countering hybrid threats; operational cooperation including maritime issues; cyber security and defence; defence capabilities; defence industry and research; parallel and coordinated exercises; defence and security capacity-building.

11 Statement on the implementation of the Joint Declaration signed by the President of the European Council, the President of the European Commission, and the Secretary General of the North Atlantic Treaty Organization of 6 December 2016 and Annex (Common set of proposals for the implementation of the Joint Declaration).

12 Implementation Plan on Security and Defence presented to the Council of 14 November 2016 (14392/16). 
tion» - developing a stronger Union in security and defence, which is able to tackle today's threats and challenges more effectively, with the right capabilities, tools and structures to deliver more security for its citizens. Moreover, it outlines the goals that the EU and its Member States set out to achieve within the three priorities which are mutually reinforcing - responding to external conflicts and crisis, capacity building of partners and protecting the Union and its citizens - and puts forward concrete actions (actionable proposals) to implement the level of ambition in respect of setting capability development priorities, deepening defence cooperation, adjusting structures, tools and (financial) instruments, drawing on the full potential of the Treaty regarding PESCO and actively taking forward CSDP Partnerships ${ }^{13}$.

Subsequently the Commission's Reflection Paper on the future of the European defence, ${ }^{14}$ the Reports on the implementation of the EU Global Strategy (Years 1 and 2), ${ }^{15}$ the Civilian Capability Development Plan, the Civilian CSDP Compact ${ }^{16}$ (which aims to strengthen EU's capacity to deploy civilian crisis management missions whose objectives are to reinforce the

13 See Implementation Plan on Security and Defence, Level of Ambition, 5 and ff., especially 5 and 6, and Implementing the Level of Ambition, 19 and ff.

14 Reflection Paper on the Future of European Defence (COM(2017)315 of 7 June 2017) - which followed the Reflection Paper on the Social Dimension of Europe (COM(2017) 206 of 26 April 2017), the Reflection Paper on Harnessing Globalisation (COM(2017)240 of 10 May 2017) and the Reflection Paper on the Deepening of the Economic and Monetary Union (COM(2017) 291 of 31 May 2017). It was published to launch a debate on how the EU (now) 27 might develop by 2025 in the area of defence. - This $4^{\text {th }}$ Reflection Paper followed the White Paper on the Future of Europe. Reflections and scenarios for the EU27 by 2025 (COM(2017)2025 of 1 March 2017.

15 From Shared Vision to Common Action: Implementing the EU Global Strategy Year 1, June 2017; From Shared Vision to Common Action: Global Strategy for the European Union's Foreign and Security Policy - Implementation Report Year 2, June 2018.

16 Council Conclusions on strengthening civilian CSDP (document 9288/18 of 28 May 2018, COPS 171, CIVCOM 89, CFSP/PESC 475, CSDP/PSDC 475, RELEX 451, JAI 493), namely Next Steps, n.os 8 e 9. - On 22 May 2018 a provisional agreement was reached on a regulation establishing the European Defence Industrial Development Programme (EDIDP) that will be submitted to the EP for a vote and subsequently to the Council for final adoption and which is expected to finance the first capability projects in 2019. See also Conclusions of the Council and of the representatives of the Governments of the Member States, meeting within the Council, on the establishment of a Civilian CSDP compact, as adopted by the FA Council in its meeting held on 19 November $2017(14305 / 18$, COPS 432, CIVCOM 231, POLMIL 207, CFSP/PESC 1046, CSDP/PSDC 656, JAI 1135 of 19 November 2018) - see I (Strategic Guidelines) and II (Commitments). 
police, the rule of law and the civil administration in fragile and conflict setting) and the EU Action Plan on Military Mobility (aiming at improving mobility of military personnel, material and assets within and beyond the EU, both in PESCO and in the context of EU-NATO cooperation, by addressing the existing legal, infrastructural and procedural barriers between the EU Member States) ${ }^{17}$ were adopted. ${ }^{18}$

Within the second category - institutional and operational initiatives - in March 2017 the Council of the EU approved Conclusions on progress in implementing the EU Global Strategy in the Area of Security and Defence ${ }^{19}$ that address four main issues: i) improving CSDP crisis management structures, including a Military Planning and Conduct Capability (MPCC) for its non-military missions within the EU Military Staff (EUMS) to be reviewed by the end of 2018; ii) Permanent Structured Cooperation (PESCO); iii) Coordinated Annual Review on Defence (CARD), to be implemented on a voluntary basis; and iv) developing civilian capabilities.

Two of these issues and respective initiatives may be particularly relevant to the EU-UK relationship after Brexit: PESCO and CARD.

According to Articles 42(6) and 46 of the TEU, as well as Protocol 10, the PESCO provides a framework to deepen defence cooperation among the Member States participants - in which the participation of the UK will be admitted. After presenting in September 2017, a list of common commitments in the main areas foreseen in Protocol 10, notably defence investment, capability development and operational readiness, 23 Member States signed a joint notification on the PESCO on 13 November 2017, setting out the principles, a list of 20 binding common commitments they have agreed to undertake as well as proposals on the governance of

17 See Joint Communication to the European Parliament and the Council of 28.2.2018 (JOIN(2018) 5 final of 28 March 2018) and European Commission Factsheet on Military Mobility (available in www.eeas.europa.eu). See previously Joint Communication to the European Parliament and the Council, Improving Military Mobility in the European Union (Join(2017) 41 final, of 10 October 2017) according to which by March 2018 the High Representative and the Commission would submit an Action Plan on Military Mobility for Member States' endorsement.

18 The various initiatives have been supported at highest political level - see in particular Conclusions of the European Council of 28 June 2018, II. Security and Defence, 13. See also Conclusions of the European Council of 18 October 2018, III. External Relations (10-14).

19 Council Conclusions on progress in implementing the EU Global Strategy in the area of Security and Defence of 6 March 2017 (see Press Release 110/17 of 06/03/2017). 
PESCO ${ }^{20}$ Afterwards, the Council adopted a decision establishing PESCO and its list of (25 Member States) participants ${ }^{2122}$, leading to the adoption by the Council (in formation of the PESCO) of a first set of 17 projects (which cover areas such as training, capability development and operational readiness in the field of defence) and their participants. ${ }^{23}$

PESCO represents therefore a step further within the CSDP, through the implementation of 17 collaborative projects in three different areas (common training and exercises (2) operational domains (land, air, maritime and cyber (6)) and joint and enabling capacities ((9) bridging operational gaps)). The Roadmap for the implementation of PESCO (12/2017$12 / 2019$ ) namely provides strategic direction and guidance on how to structure further work on processes and governance, sets out a calendar for the review and assessment process of the national implementation plans, provides a timeline for agreements on possible future projects and the main tenets of a common set of governance rules for projects. Finally, the FA Council ${ }^{24}$ adopted a Council Decision establishing a common set of governance rules for PESCO projects, ${ }^{25}$ in order to provide a framework able to ensure coherent implementation compatible with PESCO projects.

20 Notification on Permanent Structured Cooperation (PESCO) to the Council and to the High Representative of the Union for Foreign Affairs and Security Policy.

21 Council Decision establishing Permanent Structured Cooperation (PESCO) and determining the list of the Participating Member States (all except Denmark, UK and Malta - 14866/17, CORLC 548, CFSP/PESC 1063, CSDP/PSDC 667, FIN 752, 8.11.2017) - Council Decision (CFSP) 2017/2315 of 11 December 2017 establishing permanent structured cooperation (PESCO) and determining the list of participating Member States, OJ L 331, 14/12/2017, p. 57.

22 See also Declaration on PESCO projects by member states participating in PESCO.

23 Council Decision establishing the list of projects to be developed under PESCO (6393/18, CORLX 98, CFSP/PESC 169, CSDP/PSDC 83, FIN 145, 1.3.2018) and Council Decision (CFSP) 2018/340 of 6 March 2018 establishing the list of projects to be developed under PESCO (OJEU L65 of 8/3/2018, p. 24). - See also Council Recommendation concerning a roadmap for the implementation of PESCO (6588/1/18 VER 1, CORLX 123, CFSP/PESC 196, CSDP/PSDC 93, FIN 174, 6.3.2018).

24 Conclusions on Security and Defence in the context of the EU Global Strategy, document 10246/18 of 25 June 2018, Annex (CFSP/PESC 589, CSDP/PSDC 351, COPS 227, POLMIL 91, CIVCOM 122). The informal meeting of the EU Ministers of Defence of 4-5 May 2018 decided to adopt more projects later in the end of 2018, including military mobility, most relevant within EU-NATO cooperation

25 Ibid, Annex, Permanent Structured Cooperation, 1. and Council decision establishing a common set of governance rules for PESCO projects. 
In the perspective of the future EU-UK relationship after Brexit PESCO is rather relevant since it is one of the new instruments in the field of CSDP in which the participation of the UK would be expressly envisaged during the transition period and after its end (see below III.) - although the conditions for third State participation in PESCO projects have not been yet established by the Council.

Moreover, since the EU Global Strategy called for a gradual synchronisation and mutual adaptation of national defence planning cycles and capability development practices to enhance strategic convergence between Member States and facilitate and promote defence cooperation among them, CARD is envisaged as an instrument to help foster capability development addressing shortfalls, deepen defence cooperation and ensure more optimal use, including coherence, of defence spending plans. Its objective is to develop on a voluntary basis a more structured way to deliver identified capabilities based on greater transparency, political visibility and commitment of Member States. ${ }^{26}$

Although UK participation in CARD is not expressly foreseen after the end of the transition period it may not be completely out of question that the UK may have some participation in CARD within one of the guidelines regarding the EU-UK future relationship in the field of CFSP (coordination).

Finally, within the third category, three financial initiatives were adopted and/or proposed: the launching of the European Defence Fund in 2017; ${ }^{27}$ the new European Peace Facility (EPF) proposed by the High Representa-

26 The EDA in cooperation with the European External Action Service (EEAS) subsequently produced a concept paper detailing the various CARD elements. The elements and procedural steps are the following: initial information (analysis of all CARD relevant information available in EDA databases or being made available by Member States), bilateral dialogues (between EDA and each member State), CARD analysis (produced by EDA that will present aggregate data and identify trends regarding defence spending plans, implementation of priorities resulting from the Capability Development Plan and relevant to defence research programmes, as well as opportunities for cooperation) to be further discussed with Member States and will form the basis of the final report to be submitted to Ministers that will present the main results of the review as well as associated recommendations (see CARD Factsheet, available at www.eeas.europa.eu). The Council agreed to initiate a CARD which a 'trail run' involving all Member States as of autumn 2017, in view of a first CARD report within 2018 and the first full CARD cycle occurs in 2019.

27 Communication from the Commission to the European Parliament, the Council, the European Economic and Social Committee and the Committee of Regions Launching the European Defence Fund (COM(2017)295 final, 7/6/2017). 
tive, as a new financial tool outside the EU multi-annual budget; and the proposal to reinforce the EU budget allocated to CFSP/CSDP in the framework of the Multiannual Financial Framework (MFF) 2021-27, meaning a reinforcement of $€ 27,5$ billion.

The EDF presents two main strands - Research and Development and acquisition - and is able to generate a total investment of $€ 5$ billion per year after 2020. Moreover, the Commission's proposal regarding the future MFF 2021-27 confirms the EDF as a key initiative within CFSP since it proposes, besides other initiatives (such as the dedicated budget for the Connecting Europe facility connected to military mobility), an envelope of $€ 13$ billion (over the 7 year period) to be dedicated to the EDF in order for the EU to step up its contribution to Europe's collective security and defence, working with its partners, especially NATO. ${ }^{28}$ In addition, the EPF is an EU off-budget fund (i.e., outside of the EU's multi-annual budget) worth of $€ 10.5$ billion (and financed through contributions by EU Member States based on a Gross Nacional income distribution key) over a period coinciding with the next MFF, to build peace and strengthen international security since it is intended to enable the financing of operational actions under the CFSP that have military or defence implications (not funded under the EU budget according to Article 41 (2) TEU) on a permanent basis, thus facilitating rapid deployment and enhancing flexibility ${ }^{29}$ to the extent that the framework of the future EU-UK relationship does not exclude the participation of the UK in EU military missions and operations, the terms of participation of the UK in its financing, (namely through the EPF), will have to be further considered.

Finally, besides the outlined developments and adoption of new initiatives, by the EU in the framework of EU Global Strategy, a last development must be mentioned concerning EU-NATO's closer cooperation. In this respect, both the above mentioned Warsaw EU-NATO Joint Declaration of 8 July 2016 in order to strengthen and deepen the cooperation and the

28 This increase, including in respect of EU-NATO projects, probably takes into consideration the weight of the UK in defence spending within NATO (see the document Defence Expenditure of NATO Countries (2010-2017), 29 June 2017 (Communique PR/CP(2017) 111, available at nato.int). - See also European Commission Press Release EU budget for 2021-2027: Commission welcomes provisional agreement for the future European Defence Fund (IP/19/1296 of 20 February 2019).

29 The EPF will also draw together existing off-budget mechanisms, namely the Athena and the African Peace Facility, increasing the common financing of the cost of military operations. 
endorsement of a common set of (42) proposals for its implementation demonstrates that despite the evolution on the field of EU defence the partnership with NATO remains essential to its future in a complementary (by the time not competing) perspective on key areas of mutual interest. Furthermore, in order to consolidate progress and ensure further advances in all areas, both the EU and NATO Councils endorsed in 2017 a common set of new proposals, ${ }^{30}$ including a total of further 32 concrete actions for the implementation of the Joint Declaration and addressing new topics, namely counter-terrorism, military mobility and promoting the role of women in peace and security. ${ }^{31}$ Finally, a new Joint declaration of EU-NATO cooperation was signed on 8 July 2018 according to which the progress will continue to be reviewed on a yearly basis.

The issue of EU-NATO cooperation is also relevant to the shaping of the EU-UK relationship, since the UK seems to envisage NATO as a cornerstone of European defence - and therefore it is possible that it will not fully participate in EU CSDP initiatives that may jeopardize the prominence of NATO's role in such respect.

The above mentioned developments show that after a long period since the approval of the European Security Strategy $(2003)^{32}$ and almost a decade after the signature of the Treaty of Lisbon, the EU is trying hard to push forward further developments in the field CFSP and CSDP within EU's External Action - although not yet at the stage of taking a (unanimous) European Council decision on the establishment of a 'common defence' (as foreseen in Art. 42 (2) TEU).

30 Common set of new proposals on the implementation of the Joint Declaration signed by the President of the European Council, the President of the European Commission and the Secretary General of the North Atlantic Treaty Organization of 5 December 2017.

31 See also Council Conclusions on the implementation of the Joint Declaration by the President of the European Council, the President of the European Commission and the Secretary General of NATO (14801/17, CFSP/PESC 1057, CSDP/ PSDC 661, COPS 372, POLMIL 153, EUMC 147 of 5 December 2017). The next report on progress on implementation was expected to be presented in June 2018 (see Conclusions, no 7) and was presented in 31 May 2018.

32 European Security Strategy - A Secure Europe in a Better World» of 12/12/2003. See also, afterwards, the 2008 Report on the implementation of the ESS - Providing Security in a Changing World. 
It may be concluded from the 2016-18 CFSP, especially CSDP, ${ }^{33}$ developments and the whole of the concrete initiatives and instruments adopted by the EU within the framework of the EU Global Strategy and its ambitious goals, that a new path seems to arise in this field of competences: $\mathrm{i}$ ) the reinforcement of the EU autonomous strategy regarding CFSP/CSDP (and at the same time of the cooperation with the EU partners in the framework of a multilateralism approach); ii) strong efforts to strengthen effective cooperation between Member States in the area of CSDP through a wide range of initiatives, including PESCO, to improve Member States defence capabilities; iii) clear reinforcement of the (EU and Member States) financing of CFSP/CSDP either through the increase of EU budget, or through specific financial instruments within the EU budget (EDF) or outside (EPF); iv) despite the aim of reinforcement of the EU autonomous strategy regarding CFSP/CSDP and the strengthen of CSDP cooperation between EU Member States, the simultaneous reinforcement of the participation of the EU in collective defence in the framework of NATO with a complementary approach.

That is therefore the overall context and framework which the design of the future relationship between the EU and the UK regarding CFSP and CSDP will have to consider and on which the terms of the future cooperation (during and after the transition period) may depend regarding its scope, nature and instruments.

Regarding the concrete participation of the UK in the CFSP and CSDP, four main periods can therefore be identified in the light of Brexit: (i) preEU Global Strategy, (ii) post-EU Global Strategy, (iii) transitional period (from the entering into force of the Withdrawal Agreement until the end of the transitional period) and finally (iv) post-transitional period.

Until the endorsement of the EU Global Strategy at political level, the UK participated in the CFSP/CFSP as a full Member State, namely in the CFSP decision making process, in the financing of the CFSP through the EU budget, in the CSDP initiatives and in some of the EU missions and operations (on a voluntary basis). After the post-EU Global Strategy, the UK can also fully participate in the CFSP/CSDP decision making process and initiatives as an EU Member State, even though it has chosen not to participate fully in all new CFSP initiatives since it has not signed the joint declaration on PESCO as a participant Member State and therefore will

33 For an overall view see Jochen Rehrl (ed.), Handbook on CSDP, The Common Security and Defence Policy on the European Union, 3rd edition, 2017 (available at eeas.europa.eu). 
only participate as a third State (according to the requirements that will be adopted by the EU in this respect). The participation of the UK in the CFSP/CSDP during the transition period and after the end of the transition period ending 30 May 2020 are foreseen, respectively, in the Withdrawal Agreement and in the Political Declaration setting out the framework for the future relationship between the EU and the UK of 25 November 2018 - and the terms of the UK participation in the CFSP and PCSD during those two periods (and further explained in III., A. and B. below) are progressively limited and will probably evolve mainly on the basis of a third State status.

Before the analysis of the final versions of the Withdrawal Agreement and in the Political Declaration some indicators concerning the future EUUK relationship in the field of CFSP/CSDP may be found in some initiatives and documents addressing this subject, both in the EU and the UK perspectives (II, A. and B. below).

Moreover, as addressed above (see III. and IV), the future EU-UK relationship in the field of foreign policy, security and defence will take into consideration the values on which the post-EU Global Strategy, including in the field of CFSP/CSDP, is based - as a common ground for cooperation - and will also consider the participation of the UK in EU instruments and structures aimed at achieving some of the objectives laid down in the EU Global Strategy, such as the EU integrated approach to conflicts and crisis in which EU missions and operations play an important role (and the participation of the UK is also envisaged), or the European Defence Agency.

\section{Initiatives addressing CFSP and CSDP after Brexit: the EU and the UK perspectives}

\section{A. The EU Perspective}

After the 23rd June referendum and following the United Kingdom's notification under Article 50 TEU on 29 March 2017 of its intention to withdraw from the EU and Euratom, several documents have been adopted since then by different EU institutions: the European Council, the Council, the European Parliament (EP) and the Commission, under the form of either guidelines, negotiation directives, resolutions and finally the Withdrawal Agreement.

From the EU perspective - and in the sequence of the principles set out in the statement of Heads of State or Government and of the Presidents of 
the European Council and the European Commission on 29 June 2016 the most relevant political documents to the shaping of the EU-UK relationship in the field of CFSP/CSDP, during and after the transition period (to be addressed either in the Withdrawal Treaty and in a Political Declaration) are those adopted by the European Council and the European Parliament.

The EP Resolution of 14 March $2018^{34}$ addresses, besides other issues, the Framework of the future relationship of the EU and the UK, under the form of a political declaration associated with the Withdrawal Agreement, the (nine) principles that are a condition of the endorsement of such Framework by the EP, the future negotiation of an association agreement as an appropriate framework for the future relationship and the four pillars on which the future relationship should be based according to the $\mathrm{EP}^{35}$. In those four pillars, the EP includes, besides trade and economic relations, internal security and thematic cooperation, also foreign policy, security cooperation and development cooperation. Specifically regarding foreign policy and security cooperation (and development cooperation), the EP namely admits that, although the UK as a third country will not be able to participate in the EU's decision-making process, consultation mechanisms are not excluded in order to allow the UK to align with EU foreign policy positions, joint actions or multilateral cooperation, especially in the framework of the UN, OSCE and Council of Europe, and supports coordination on sanction policy and implementation; that such partnership (under the Framework Participation Agreement) would make it possible for UK participation (with no lead role) in civilian and military missions and EU operations, programmes and projects in different areas, including projects developed under PESCO; that any cooperation in such areas that involves shared EU classified information including on intelligence is conditional on a security information agreement; that the UK could participate, based on other similar third country arrangements, in EU programs in support of defence and external security and the EU is open to the possibility of the

34 Guidelines on the Framework of the future EU-UK Relations - European Parliament Resolution of 14 March 2018 on the Framework of the future EU-UK relationship (2018/2573(RSP) - P8_TA-PROV(2018)0069), following its previous resolutions of 5 April 2017 on negotiations with the United Kingdom following its notification that it intends to withdraw from the European Union and of 3 October 2017 and of 13 December 2017 on the state of play of negotiations with the United Kingdom (respectively Texts adopted, PA_TA(2017)0102, PA_TA(2017)0361 and PA_TA(2017)0490).

35 Ibid, especially $2,4,5$ and $\overline{6}$. 
UK continuing to contribute to EU's external financing instruments in pursuit of common objectives, especially in the common neighbourhood policy; and finally that EU-UK cooperation in development, cooperation and humanitarian aid would be mutually beneficial. ${ }^{36}$

The Guidelines approved by the European Council that are relevant to the future EU-UK relationship are those adopted, successively, on 29 April 2017, 15 December 2017 and 23 March 2018.

Firstly, in the Guidelines approved on 29 April 2017 that define the framework for negotiations under Article 50 TEU and set out the overall positions and principles that the Union will pursue throughout the negotiation $^{37}$ have not set aside the issue of CFSP and CSDP. In fact, besides some other references to the international relations field and international (EU or mixed) agreements, ${ }^{38}$ a specific mention is made to security, defence and foreign policy stating that the EU 'stands ready to establish partnerships in areas unrelated to trade, in particular the fight against terrorism and international crime, as well as security, defence and foreign policy'. ${ }^{39} \mathrm{Al}-$ though relevant, the CFSP and CSDP seemed not to be, from the EU perspective, a top priority to be addressed within the first phase of the negotiation of the withdrawal agreement. ${ }^{40}$

36 Ibid, (ii) Foreign policy, security cooperation and development cooperation, no 21-25.

37 Special meeting of the European Council (Art. 50) of 29 April 2017, Guidelines following the United Kingdom's notification under Article 50 TEU. See also the resolution of the European Parliament of 5 April 2017 (EUCO XT 20004/17, BXT 10, CO EUR 5, CONCL 2 of 29 April 2017).

38 Ibid, II.A phased approach to negotiations, especially 4 and 13 (this regarding the issues of (international) agreements concluded by the EU or by the Member States on its behalf or by the Union and its Member States acting jointly).

39 Ibid, IV. Preliminary and preparatory discussions on a framework for the Union United Kingdom future relationship, 22.

40 In the subsequent Guidelines adopted at the Special meeting of the European Council (under art. 50 TEU) following the United Kingdom's notification under Article 50 TEU on 29 March 2017 of its intention to withdraw from the EU and Euratom the abovementioned trend was a constant. - The Directives for the negotiation of an agreement with the United Kingdom of Great Britain and Northern Ireland setting out the arrangements for its withdrawal from the European Union (Annex to the Council Decision authorising the opening of negotiations with the United Kingdom of Great Britain and Northern Ireland for an agreement setting out the arrangements for its withdrawal from the European Union (XT 21016/17, ADD 1 REV 2, BXT 24 of 22 May 2017)) does not expressly address CFSP and CSDP but includes a reference to a constructive dialogue on a common possible approach towards third country partners, international organisations and conventions in relation to the international commitments contracted before the with- 
Afterwards, in the Guidelines adopted on 15 December 2017, the European Council reconfirms its readiness to establish the above-mentioned partnerships, including security, defence and foreign policy - although no specific guidelines are set in this respect. ${ }^{41}$

Finally, in the Guidelines adopted on 23 March 2018, the European Council reiterates the determination of the EU to have as close as possible a partnership with the UK in the future that should cover other areas than trade and economic cooperation, in particular the fight against terrorism and international crime, as well as security, defence and foreign policy. ${ }^{42}$ In this document the European Council also took into account the stated positions of the UK, which limit the depth of future partnership, thus setting out further guidelines with a view to the opening of negotiations on the overall understanding of the framework for the future relationship, that will be elaborated in a Political Declaration accompanying and referred to in the Withdrawal Agreement. ${ }^{43}$ The European Council considers that in view of the shared values between EU and UK 'there should be a strong EU-UK cooperation in the fields of foreign, security and defence policy' while 'a future partnership should respect the autonomy of the Union's decisionmaking, taking into account that the UK will be a third country, and foresee appropriate dialogue, consultation, coordination, exchange of information, and cooperation mechanisms. As a pre-requisite for the exchange of information in the framework of such cooperation a Security of Information Agreement would to have to be put in place'. ${ }^{44}$ No further indication regarding such strong EU-UK cooperation is given by the 2018 guidelines.

drawal date, by which the UK remains bound (and therefore to mixed agreements) $-c f$ no18.

41 European Council (Art. 50) meeting (15 December 2017) - Guidelines (EUCO XT 20011/17, BXT 69, CO EUR 27, CONCL 8, 15 December 2017), no 8. These Guidelines were preceded by the Communication from the Commission to the European Council (Article 50) on the state of the progress of the negotiations with the United Kingdom under Article 50 of the Treaty on European Union $(\operatorname{COM}(2017) 784$ final of 8 December 2017) and the Joint report from the negotiators of the European Union and the United Kingdom Government on progress during phase 1 of negotiations under Article 50 TEU on the United Kingdom's orderly withdrawal from the European Union of 8 December 2017.

42 European Council (Art. 50) meeting (23 March 2018) - Guidelines on the framework for the future EU-UK relationship (EUCO XT 20001/18, BXT 25, CO EUR 5, CONCL 2, 23 March 2018), no 3.

43 Ibid, no 5.

44 Ibid, no 13, ii). The European Council will follow the negotiations closely, in all their aspects, and will return to the remaining withdrawal issues and to the Framework for the future relationship at its June meeting (no 16). 
Afterwards, ${ }^{45}$ the Chief negotiator M. Barnier stated that the UK's commitment to Europe's security as restated in the UK paper Framework for the UK-EU Security Partnership of 9 May 2018 was welcome and that the future EU-UK relationship could be underpinned by a set of the (above mentioned 5) mechanisms set up in the 23 March 2018 European Council's Guidelines - dialogue, consultation, coordination, cooperation and exchange of information. Elaborating further on these mechanisms, the Chief negotiator indicates that future partnership could include five dimensions: i) close and regular consultations with the UK on foreign policy; ii) when projecting the EU's support worldwide, EU will be open to the UK's contribution; iii) in defence matters the UK should have the possibility (where it adds value) to actively take part in a number of the European Defence Agency's Research and Technology projects; iv) exchanging information in incidents that makes the partners more effective in fighting cyber-attacks; v) a EU-UK Security of Information Agreement.

From the point of view of the EU-UK post-Brexit relationship, it can be concluded that the above-mentioned documents contributed to shape the draft of the Withdrawal Agreement and the subsequent Political Declaration setting out the framework for the future EU-UK relationship specifically in the field of CFSP/CSDP. Some main ideas arise from these documents. First, that both parties, despite their respective autonomy, agree to a partnership in the foreign, security and defence policy, based on a set of five instruments (dialogue, consultation, coordination, cooperation and exchange of information) and where concrete thematic areas of mutual interest exist (and therefore allowing UK alignment or participation - at least as a third State) are already identified: policy of international sanctions; EU civilian and military missions and operations; EU defence projects through the EDA; and, more generally, cooperation within International Organisations (UN, Council of Europe, OSCE) and exchange of information. Second, the UK participation can take place either through existing instruments (used with third States, such as a Framework Participation Agreement for EU missions and operations or an Administrative Agreement regarding the EDA) or new models of closer cooperation. Therefore, al-

45 See Speech/18/3785, delivered on the 14th May High Level panel discussion on 'The future of EU foreign, security and defence policy post Brexit' at EU Institute for Security Studies, Brussels (available at TF50, www.ec.europa.eu.) - where he stated that the security of the EU and the UK is bound together, although there is still a lot of uncertainty, and there should be no uncertainty about the EU commitment to a future security partnership since the challenges are by their nature cross border. 
though the participation of the UK as a (mere) third State can be admitted, the envisaged EU-UK 'strong cooperation' in the fields of foreign policy, security and defence neither explicitly admits nor excludes a different third State status.

All the topics addressed by the EP Resolution and the European Council Guidelines still would have to be more detailed in the text of Withdrawal Agreement and in the Political Declaration which the first refers to (as well as in subsequent future EU-UK agreements that will apply after the transition period).

Within the framework of the Guidelines adopted by the European Council (29 April 2017 and 15 December 2017), the Commission adopted on the 28 February 2018 a Draft Withdrawal Agreement ${ }^{46}$ which contains articles with references to CFSP and Security and Defence both in Part Four (Transition) and Part Five (Financial provisions). The main steps of the subsequent path that led to the approval of the (final) text of the Agreement on the Withdrawal of the UK from the EU can be summarized as follows.

At the informal meeting of the heads of State or government held on 19-20 September 2018 in Salzburg, EU's 27 leaders agreed to have a joint political declaration setting out the framework of the future relations between the EU and the $U K$ in different areas, including in the area of security and defence, thus providing as much clarity as possible in the future relations. ${ }^{47}$

46 Draft Withdrawal Agreement on the withdrawal of the United Kingdom of Great Britain and Northern Ireland from the European Union and the European Atomic Energy Community,TF50 (2018) 33 - Commission to EU 27 (to be presented to the Chief negotiator to the CRP Art. 50 and to the Brexit Steering Group on 28 February 2018 and to be further discussed with the Council (Art. 50) and the Brexit Steering Group before transmission to the UK authorities for negotiation (see the TF50 at www.ec.europa.eu). The subsequent document TF50(2018) 35 Commission to EU27, of 19 March 2018 contains the Draft Agreement highlighting the progress made (coloured version) in the negotiation round with the UK of 16-19 March 2018. The text of the Draft Withdrawal Agreement was published at the website of the UK Government (www.gov.uk/policies/brexit).

47 In this informal meeting the EU leaders also agreed that there will be no Withdrawal Agreement without a solid, operational and legally binding Irish backstop. - See also Preparing for the withdrawal of the United Kingdom from the European Union on 30 March 2019 - Communication from the Commission to the European Parliament, the European Council, the Council, the European Central Bank, the European Economic and Social Committee, the Committee of the Regions and the European Investment Bank - COM(2018) 556 final of 19/7/2018, as corrected by $\operatorname{COM}(2018) 556 \mathrm{final} / 2$, of 27/8/2018. 
An understanding on pending issues was achieved and a final version of text of the Draft Agreement on the Withdrawal of the UK from the EU, as agreed at the negotiator's level on 14 November 2018 was presented ${ }^{48}$ together with an outline of a Political Declaration setting out the framework for the future relationship between the EU and the UK, as agreed at negotiator's level on the same date. ${ }^{49}$

Subsequently, the special meeting of the European Council (Art. 50) of 25 November 2018 endorsed the draft Brexit withdrawal agreement and approved the draft Political Declaration on the future EU-UK relations. ${ }^{50}$

Subsequently, on 11 January 2019 the Council (Art. 50) adopted a decision on the signing of the withdrawal agreement as well as one draft decision on the conclusion of the withdrawal agreement which was forward to the EP for its consent. ${ }^{51}$ Both the text of the Instrument relating to the withdrawal agreement (which constitutes a document of reference that will have to be made use of if any issue arises in the implementation of the Withdrawal Agreement having legal force and binding character to this effect) and of the Joint Statement supplementing the Political Declaration setting out the framework for the future relationship between the European Union

48 TF50 (2018) 55 - Commission to EU27 of 14 November 2018.

49 TF50 (2018) 56 - Commission to EU27 of 14 November 2018.

50 Conclusions, EUCO XT 20015/18, BXT 110, CO EUR 27, CONCL 8 of 25 November 2018. These Conclusions were reconfirmed in the special meeting of the European Council (Art. 50) of 13 December 2018 (Conclusions, EUCO XT 20022/18, BXT 131, CO EUR 32, CONCL 9 of 13 December 2018). In the 25 November Conclusions the European Council also invited the EP and the Commission to take the necessary steps to ensure that the agreement can enter into force on 30 March 2019, so as provide for an orderly withdrawal. See previous Document BXT 111 CO EUR-PREP 54 of 22 November 2018 and Annex.

51 Council Decision (EU) 2019/274 of 11 January 2019 on the signing, on behalf of the EU and of the European Atomic Energy Community, of the Agreement on the withdrawal of the United Kingdom of Great Britain and Northern Ireland from the European Union and the European Atomic Energy Community, [2019] OJ L 47 I/1, and attached text of the Withdrawal Agreement (published in [2019] OJ C 66 I/01). The text of the Political Declaration was published in [2019] OJ C $66 \mathrm{I} / 02$. - See also previous documents $\operatorname{COM}(2018) 833$ final and $\operatorname{COM}(2018) 834$ final of 5 December 2018; Council Decision on the signing, on behalf of the EU and of the European Atomic Energy Community, of the Agreement on the withdrawal of the United Kingdom of Great Britain and Northern Ireland from the European Union and the European Atomic Energy Community - XT 21106/18, BXT 125 of 7 January 2019; Council Decision on the conclusion of the Agreement on the withdrawal of the United Kingdom of Great Britain and Northern Ireland from the European Union and the European Atomic Energy Community - XT 21105/18, BXT 124 of 9 January 2019. 
and the United Kingdom of Great Britain and Northern Ireland ${ }^{52}$ were approved in the special meeting of the European Council (Art. 50) of 21 March 2019.53

Following the position of the House of Commons declining to approve the Withdrawal Agreement and the subsequent request of the UK on 5 April 2019 for a further extension ${ }^{54}$ to the Article 50 period until 30 June 2019, the special summit of the EU leaders on 11 April finally agreed to a further extension of Article 50 in any event no longer than 31 October 2019 and the EU decision taken in agreement with the UK extending the period of Article 50 was approved. ${ }^{55}$ During the extension period, the UK will remain a Member State with full rights and obligations in accordance with the same Article 50; the UK has a right to revoke its notification at any time; and the Withdrawal Agreement may enter into force on an earlier date, should the parties complete their respective ratification procedures before 31 October $2019^{56}$.

Finally, Council Decision (EU) 2019/642 on the signing of the Withdrawal Agreement was adopted ${ }^{57}$ - an adapted draft decision on the con-

52 Annex to the document XT 21014/19, BXT 15, CO EUR-PREP 10 of 20 March 2019 (Instrument relating to the Agreement on the Withdrawal of the United Kingdom of Great Britain and Northern Ireland from the European Union and the European Atomic Energy Community); annex to the document XT 21018/19, BXT 24, CO EUR-PREP 11 of 20 March 2019. Both these texts have been agreed at the negotiator's level, agreed between UK Prime Minister and the President of the European Commission on 11 March 2019 in Strasbourg and have been endorsed by the Commission on the same day.

53 Conclusions, 2 (EUCO XT 20004/19, BXT 20, CO EUR 7, CONCL 2 of 21 March 2019).

54 See European Council Decision (EU) 2019/476 taken in agreement with the United Kingdom of 22 March 2019 extending the period under Article 50(3)TEU [2019] 80I/1); see also previous document European Council Decision taken in agreement with the United Kingdom, extending the period under Article 50(3) TEU (EUCO XT 20006/19, BXT 26 of 22 March 2019).

55 Conclusions of the special meeting of the European Council, 2 (Art. 50), EUCO XT 20015/19, BXT 40, CO EUR 9, CONCL 4 of 10 April 2019; European Council Decision (EU) 2019/584 taken in agreement with the United Kingdom of 11 April 2019 extending the period under Article 50(3)TEU ([2019] OJ L101/1); see also previous document European Council Decision taken in agreement with the UK extending the period under Article 50(3) TEU (EUCO XT 20013/19, BXT 38 of 11 April 2019).

56 Ibid, 6.

57 Council Decision (EU) 2019/642 of 13 April 2019 amending Decision (EU) 2019/274 on the signing, on behalf of the EU and of the European Atomic Energy 
clusion of such agreement ${ }^{58}$ was also adapted and attached to that Decision. ${ }^{59}$

From the point of the CFSP/CSDP post Brexit, three aspects of the 2019 developments and in particular of the European Council decision of 11 April 2019 must be underlined: i) since the further extension of the period of Article 50(3) TEU must not undermine the regular functioning of the Union and its institutions, the UK fully participates on the decision making procedures regarding CFSP/CSDP in this period; ii) since the extension excludes any re-opening of the Withdrawal Agreement and cannot be used to start negotiations on the future relationship, it does not affect the terms laid down in the Withdrawal Agreement regarding CFSP/CSDP which would apply during the transition period; iii) the Joint Statement supplementing the Political Declaration setting out the framework for the future relationship between the EU and the UK agreed in March 2019 does not affect the framework already set in the Political Declaration (of 22 November 2018) concerning the future relationship in the field of CFSP/ CSDP (see III, A. and B. below).

\section{B. The UK perspective}

On the UK official side, the consequences of the Brexit regarding the future relationship with the Union regarding the CFSP and CSDP were worth attention, both at the government and at the Parliament level. In

Community, of the Agreement on the withdrawal of the United Kingdom of Great Britain and Northern Ireland from the European Union and the European Atomic Energy Community ([2019] OJ L 110 I/1) and previous document Council Decision on the signing, on behalf of the EU and of the European Atomic Energy Community, of the Agreement on the withdrawal of the United Kingdom of Great Britain and Northern Ireland from the European Union and the European Atomic Energy Community - XT 21027/19, BXT 44 of 11 April 2019.

58 Council Decision on the conclusion of the Agreement on the withdrawal of the United Kingdom of Great Britain and Northern Ireland from the European Union and the European Atomic Energy Community (adapted text) - XT 21105/18, REV 2, BXT 124 of 11 April 2019.

59 Agreement on the Withdrawal of the United Kingdom of Great Britain and Northern Ireland from the European Union and the European Atomic Energy Community, XT 21028/19 BXT 45 of 11 April 2019 - the adapted text was published in [2019] OJ C144 I/1 and attached to Council Decision (EU) 2019/642. The subsequent references to articles of the Withdrawal Agreement will refer to this final (adapted) text. 
this respect are, among others, worth mentioning: the so called 'Brexit White Paper' - The United Kingdom's exit from and new partnership with the European Union ${ }^{60}$ - since it details out the (12) principles which would guide the Brexit, including regarding European security; short afterwards the Evidence session held by the EU External Affairs Sub-Committee on Common Foreign Security Policy (CFSP) post Brexit; ${ }^{61}$ as well as the previous House of Lords Library Note Leaving the European Union: Foreign and Security Policy Cooperation ${ }^{62}$ - the last two because they address a wide range of issues in respect of the EU-UK relationship in the field of CFSP/CSDP and possible models for the future cooperation.

Afterwards, more recent documents are also relevant in respect of the EU-UK relationship after Brexit in the area of CFSP and CSDP, namely the Framework for the UK-EU Security Partnership of 9 May $2018^{63}$ or the Technical note on consultation and cooperation on external security of 24 May 2018 (DExEU Policy paper) ${ }^{64}$ which in particular contains a more detailed list of proposals of what the future UK-EU consultation and cooperation in that

6017 January 2017 (text available at www.gov.uk/government/uploads/system/uploa ds/attachment_data/file/589191/The_United_Kingdoms_exit_from_and_partners hip_with_the_EU_Web.pdf).

61 One-off Evidence session with Professor Richard Whitman and Professor Karen Smith held on 6 April 2017 by the EU External Affairs Sub-Committee on Common Foreign Security Policy (CFSP) post-Brexit (www.parliament.uk/business/co mmittees/committees-a-z/lords-select/eu-external-affairs-subcommittee/news-parlia ment-2015/academics-common-foreign-security-policy/ and video and audio at www.parliamentlive.tv/Event/Index/e6a38ead-7c7e-4a97-9d72-ec93b0d3dd62). The reference of the transcript of the evidence taken in public in this paper is made considering the contents of numbers 1 and 2 on the 'Use of the transcript'.

62 House of Lords Library Note Leaving the European Union: Foreign and Security Policy Cooperation of 13 October 2016 (LLN 2016/051). See also House of Commons Library, Briefing Paper Number CBP7798, 31 March 2017, Brexit: implications for national security (by Joanna Dawson, text available in www.researchbriefings.files. parliament.uk) and House of Commons Library, Briefing paper Number CBP 774212 June 2017, Brexit reading list: defence and security, in particular 5. Future cooperation (text available in https://www.researchbriefings.files.parliament.uk).

63 Policy paper, Framework for the UK-EU Security Partnership, published on 9 May 2018, Department for Exiting the European Union (available at www.gov.uk/ Department for Exiting the European Union).

64 Available at www.gov.uk/ Department for Exiting the European Union - see also www.parliament.uk/brexit (see Committees/Exiting the European Union Committee). See more recently House of Lords, European Union Committee, 16th Report of Session 2017-19, Brexit: Common Security and Defence Policy missions and operations and Government response (available at www.publications.parliament.u $\mathrm{k})$. 
area may be - both subsequent to the Draft Withdrawal Agreement of February 2018.

An overview of the contents of such documents (as detailed below) allows a preliminary conclusion that a partial convergence may exist with the EU position in respect of the EU-UK relationship after Brexit in the field of the CFSP/CSDP. Firstly to an extent that dialogue, cooperation, coordination and consultation in general are envisaged by both parties. Secondly, because the alignment of the EU-UK positions in foreign policy is also a possibility for the EU and the UK, namely in respect of sanctions and participation in international organisations and fora. Thirdly because close participation of the UK in EU civilian and military missions and operations and some EU agencies, such as the European Defence Agency, is also admitted by both.

However, two main issues seem to drive the EU and the UK apart. Firstly, the status of the UK, since the EU seems to admit UK's cooperation and participation as a third State - and expressly neither admits nor exclude a differentiated third State status - while the UK in the mentioned documents does not put aside a model of cooperation and participation that may go beyond the current model of participation of third States in EU CFSP/CSDP. Secondly, the relationship with NATO as a corner stone of European defence - that may be jeopardised by the development of a more integrated CSDP within the EU which seems to be one of the more evident consequences of the implementation of the EU Global Strategy.

The (chronologically first) document - House of Lords Library Note Leaving the European Union: Foreign and Security Policy Cooperation - expressly addresses current cooperation of the UK within the EU vs future prospects regarding CFSP and CSDP ${ }^{65}$. The Note addresses a wide range of issues, namely those regarding: the (direct) institutional consequences of Brexit (the end of the participation of the UK in several EU organs such as the FA Council or the EEAS); the consequences of Brexit in respect of international agreements binding the UK, especially the issue of replacement of international agreements in which the UK is part because of its membership of the EU (mixed agreements or EU agreements, depending on the category of competences), Association agreements or Partnership Cooperation agreements within ENP (renegotiation, changing the title of its binding nature (UK itself instead of UK as an EU Member State)); the future

65 See 2. Common Foreign and Security Policy, 2.3 Future Prospects, 3. Common Security and Defence Policy, 3.3 Future Prospects (and 4. Security and Policy Cooperation, 4.3 Future Prospects). 
possibility of alignment with EU foreign policy positions, including implementing sanctions, as a third country, since the EU already allows nonMember States to align themselves with EU common positions despite no involvement in its formulation (vg cases of Norway and Switzerland); the future possibilities regarding cooperation with the EU in the (sub-area of CFSP) CSDP, bearing in mind naturally the terms of the current UK involvement as a Member State within CSDP and its implementation - participation in military CSDP missions/operations and CSDP civilian missions, participation in initiatives within the CSDP to improve the military assets and capacities of EU Member States (European Defence Agency, EU Battlegroups and UK as Lead Nation). In this regard, the main topics for the future path seemed to envisage the UK as a 'Key player in European defence' through NATO (and therefore US) and cooperation between NATO and the EU (in the line of the Warsaw Declaration); the possibility of future cooperation with the EU in missions that are in the UK interest, or in theory even of participation in the EDA or EU Battlegroups. In fact, non-EU members have already participated in EU CSCP (military and civilian) missions and operations (though with different levels of involvement) and can also participate in the EDA through Administrative Agreements approved at the level of the EU Council (that is the case of Norway (2006), Switzerland (2012), Republic of Serbia (2013), Ukraine (2015)). Non-EU Member States can also be invited by Member State and therefore participate in the EU Battlegroups (e.g. Norway and Nordic Battlegroup).

One of the issues worth attention in the Note was of course the impact of Brexit on the prospects of further European defence integration and a future European army because of the alleged risks to undermine NATO as a cornerstone of European defence (to which the UK as EU Member State has opposed). To sum up, three different models are envisaged, depending upon the preferences both of the UK and the EU partners: commitment on European security through NATO, continuing the participation in EU structures and operations as a third country (nevertheless the fact that its design may change after the Brexit towards a more integrated EU CSDP) and bilateral relations with EU partners (such as France).

In January 2017 Brexit White Paper, the reference to the CFSP and CSDP is rather short and generic. ${ }^{66}$ In this respect, it is intended in general that the UK 'will continue to be one of the most important actors in interna-

66 See 11. Cooperation in the fight against crime and terrorism, pp 61-64 (where the topics The UK in the World and European Security are addressed), especially 11.8 and 11.9 and $11.11-11.14$. 
tional affairs' considering its specific features (vg the permanent seat on the UN Security Council and the percentage of the GDP spent on defence). Besides, it is intended to use national tools and the UK privileged position in international affairs 'to continue to work with the EU on foreign policy security and defence', to continue to play a leading role alongside EU partners in buttressing and promoting European security and influence around the world and to enhance the strong bilateral relationship with the EU partners and beyond. Moreover, and remembering the UK participation and role in several CSDP military missions/operations and CSDP civilian missions the objective enounced is to 'ensure that the EU's role in defence and security is complementary to, and respects the central role of, NATO' and to 'remain committed to European Security and add value to EU foreign and security policy'. The document also underlines the intention that the UK will continue to play a leading role as a global foreign and security policy actor within NATO.

Finally in the second initiative above mentioned - Evidence session held by the EU External Affairs Sub-Committee on Common Foreign Security Policy (CFSP) post Brexit - the issue of the CFSP and CSDP post-Brexit is addressed in more detailed way, the contribution of the two Professor witnesses allowing to identify the main questions and problems involved and possible ways of shaping further relationship EU/UK in the area of EU competences in question. In this respect, three of the topics seems to be particularly relevant.

First, the one regarding the three possible models for future relationship between the UK and the EU foreign, security and defence policy as proposed by Professor Richard Whitman: ${ }^{67}$ integrated, associated and detached. It is so because it raises the issue of the will of both parties to shape a new model to address the future EU-UK relationship that goes beyond the current model and instruments of participation of third States in the present (especially in the EU sanctions policy which is more effective due to its collective nature and in the EU missions, operations and bodies such as the EDA, namely through a framework agreement or an administrative agreement), raising therefore the issue of the (in)adequacy of existing models for participation of third States in CFSP and CSDP (e.g. Norway). If such a path surely depends on both Parties political will, Brexit has put forward the possibility of a different status, i.e., ex-third State - which in-

67 RG Whitman 'The UK and EU foreign, security and defence policy after Brexit: integrated, associated or detached?' (2016), National Institute for Economic Review, 238 (1), pp 43-50. 
evitably has a common past linked to the EU integration, including in the field of CFSP/CSDP.

Second, if a new - or at least a different model - of participation of a third State is envisaged, the issue of UK participation in decision making process, or at least decision shaping process, is particularly sensitive, especially at the political level, since at present no regular participation (of third States) appears to be envisaged. In this respect one could consider the existing status of State participation in international organisations, such as (formal or informal) observers. The example of the draft agreement on the accession of the EU to the ECHR may be of interest since it foresees the participation of the EU (without being a member) in the organs of the Council of Europe that have competence regarding the ECHR.

Third, the issue of the relationship between the EU, the UK and NATO. Despite the fact that the scope of NATO is defence and EU CSDP has a wider scope, the closer EU-NATO relationship in the framework of the EU Global Strategy is parallel to the increasing reinforcement of the EU CSDP since 2017. In this respect, the approach of the EU to CSDP has changed into more autonomous EU27 capabilities and even if no unanimous decision to proceed to a common defence is (ever) reached, the reinforcement of the CSDP and of the EU Member States capabilities may have in the future, despite different political views within the NATO, repercussion in its leadership and the role of the UK in the organisation.

Therefore, it must be seen whether the (final) version of the Withdrawal Agreement as well as the Political Declaration setting out the framework for the future EU-UK relationship allows any space for new methods or instruments adapted to the UK capacity of ex-EU Member State; admit any concrete form of participation of the UK in decision shaping and making and under which terms; and foresee any particular rule regarding EU-UK cooperation within the NATO.

Besides the documents above mentioned, the Framework for the UK-EU Security Partnership on 9 May 2018, focuses on how the UK will look to achieve a new partnership with the EU which builds on the shared interests and values and goes beyond any existing third country arrangements, covering both internal and external security,and will form on the UK perspective the basis of ongoing negotiations with the EU. Furthermore, the Technical note on consultation and cooperation on external security of 24 May 2018 (DExEU Policy paper) sets out a non-exhaustive list of proposals describing what a future framework of UK-EU consultation and cooperation on external security might be, stressing that it should be flexible and scalable to enable both EU and UK to cooperate more closely when it is of their mutual interest respecting both EU autonomy and UK sovereignty. 
The proposed framework in respect of foreign policy mainly envisages consultation and cooperation: in Brussels (mainly UK/EEAS strategic talks and consultations at various levels and where appropriate with the Commission); with the EU27 that may include ad-hoc meetings with the FA Council as well as with the Political and Security Committee in informal sessions; in multilateral fora and third countries (vg EU head of Delegation and UK Embassy); on sanctions by exchange of information on listing and their justification, an EU-UK sanctions dialogue and adoption of mutually supportive sanctions - as well as the possibility of joint outcomes namely joint statements, positions and demarches. Specifically in respect of CSDP the proposed framework also foresees consultation and cooperation through the various EU institutions and relevant organs (FA Council, EUMC, EUMS); cooperation on diplomatic support for crisis management; whenever the UK participates to a EU mission or operation, the participation in the respective operational headquarters; administrative agreements with the EDA and a coordinated approach to European capability development and planning and UK participation in specific projects and initiatives and in the EDF. In particular, the last document seem to take into consideration the general rules on consultation and cooperation on foreign policy, security and defence already laid down in the Draft Withdrawal Agreement.

Despite the wide range of issues and models for cooperation considered in the documents detailed above and the convergence in some main topics allowing to shape the grounds for the future EU-UK relationship in respect of CFSP/CSDP, it cannot be ignored that the so-called (flexible and scalable) consultation and cooperation between the EU and the UK does not exclude an autonomous foreign and security policy - meaning autonomous (although convergent in some areas) internal decision making process.

Despite the mentioned convergence, the exact terms of the future relationship in the field of CFSP/CSDP - either during or after the transition period - would be definitively established both in the Withdrawal Agreement (transitional period) and in the Political Declaration of 25 November 2018 applicable after the transition period (both analysed in III. below), thus confirming some of the ways of cooperation already envisaged by both parties but also stressing out the divergences between them. 


\section{The Agreement on the Withdrawal of the UK from the European Union and the Common Foreign and Security Policy and the Political Declaration and 'Foreign Policy, security and defence'}

Both the texts of the Withdrawal Agreement and the Political Declaration setting out the framework for the future relationship between the EU and the $\mathrm{UK}^{68}$ (as mentioned in Article 184 of the Agreement and which terms will be foreseen in future agreements to be negotiated and concluded by the EU and the EU), include rules addressing issues and possible forms of cooperation in the field of CFSP and CSDP.

On one hand, the Withdrawal Agreement addresses CFSP and CSDP issues in three articles: both Article 127 ('Scope of transition'), 2 and 7(a) and 129 ('Specific arrangements relating to the Union's external action'), mainly 2, 6 and 7, of Part Four on Transition; and Article 156 ('The United Kingdom's obligations from the date of entry into force of this Agreement') in Part Five on Financial provisions. On the other hand, the Political Declaration addresses CFSP and CSDP issues in its Part III (Security Partnership, III. Foreign policy, security and defence, A. to G. (92-109).

The main differences regarding the scope of application and the contents of both texts, specifically in respect of CFSP/CSDP, can be identified as follows:

First of all, the Agreement foresees rules defining the UK legal status (rights and obligations) regarding CFSP/CSDP during the transition period (starting on the date of entry into force of the Agreement and ending on 31 December $2020^{69}$ ); and the Political Declaration, mainly foresee objectives and principles (III, 92-94) and guidelines (III, 95 and A. to G, 96 and following) regarding the future relationship in the field of 'Foreign policy,

68 All the references mentioned in the text refer to their respective versions as adapted and supplemented by 11 April 2019 - Agreement on the withdrawal of the United Kingdom of Great Britain and Northern Ireland from the European Union and the European Atomic Energy Community ([2019] OJ C144 I/1); and Political Declaration setting out the Framework for the future relationship between the European Union and the United Kingdom (XT 21095/18, BXT 111, CO EUR-PREP 54 of 22 November 2018) endorsed by the European Council of 25 November 2018 ([2019] JO C 66I/02), as supplemented by the Joint Statement supplementing the Political Declaration setting out the Framework for the future relationship between the European Union and the United Kingdom of Great Britain and Northern Ireland (XT 21018/19, BXT 24, CO EUR-PREP 11 of 20 March 2019) as endorsed by the European Council (Art. 50) of 25 November 2018 and of 21 March 2019.

69 See Arts 2(e) and 126 of the Withdrawal Agreement. 
security and defence' (as a part of a broader 'Security partnership') after the end of the transition period.

Secondly, the specific articles included in the Agreement regarding CFSP and CSDP defining the UK legal status during the transition period mainly address two forms of derogation of the general rule of Article 127 (1) of the Agreement according to which (unless otherwise provided in the Agreement) EU law, including in the field of CFSP/CSDP (Chapter 2 of Title V of the TEU i.e. 'Specific provisions on the CFSP'70) shall apply to and in the UK during the transition period: (i) a full derogation of EU rules before the end of the transition period depending on an EU-UK agreement governing their relationship in the area of CFSP which becomes applicable during the transition period (Art. 127, 2) ${ }^{71}$ as well as (ii) specific thematic derogations and an 'opt-out' clause which apply during the transition period.The specific paragraphs of the Political Declaration regarding the issue of 'Foreign policy, security and defence' mainly address guidelines identifying the mechanisms to be used in the future relationship between the EU and the UK in this field which is based, despite some common objectives, in parallel EU and UK foreign policies according to their respective strategic and security interests and in close cooperation when those interests are shared - through dialogue, consultation, coordination, exchange of information and cooperation mechanisms (Part III, III, 94-95).

Thirdly, the articles of the Agreement regarding CFSP and CSDP that foresee thematic derogations refer specifically to the application of CSDP rules - permanent structured cooperation (PESCO) and EU missions and operations (Art. 127, 7(a) and 129,7) - while the 'opt-out' clause (based on 'vital and stated reasons of national policy' - Article 129, 672) regards the non-application of a decision of the Council falling under CFSP including

70 Chapter 2 (Specific provisions on the Common Foreign and Security Policy) of Title V (General provisions on the Union's External Action and Specific provisions on the Common Foreign and Security Policy) of the TEU - including both Section 1 Common provisions (Arts 23 to 41) and Section 2 Provisions on the Common Security and Defence Policy (Arts 42 to 46).

71 In which case the rules of the TEU and respective secondary law will simply cease to apply to the UK from the date of application of that agreement. - Without prejudice to Art 127 (2), Art 129 (5) of the Withdrawal Agreement foresees that whenever there is a need for coordination, the UK may be consulted, on a case-bycase basis

72 Art 129, 6 of the Withdrawal Agreement foresees that Following a decision of the Council falling under Chapter 2 of Title V TEU, the UK may make a formal declaration to the High Representative of the Union for Foreign Affairs and Security 
CSDP (Chapter 2 of Title V of the TEU). The specific paragraphs of the Political Declaration regarding the issue of 'Foreign policy, security and defence' foresee guidelines identifying firstly the establishment of general structured consultation and regular thematic (general and sectorial) dialogues identifying areas and activities for close cooperation (III, A, 96-98) and also some specific areas of future consultation and cooperation (sanctions, crisis management missions and operations both civilian and military, defence capabilities developments, intelligence exchanges and development cooperation - III, B. to G., 99-109).

Some relevant details of both texts should still be underlined in the perspective of the CFSP and CSDP post-Brexit.

\section{A. The Agreement on the Withdrawal and the Common Foreign and Security Policy}

Four aspects of the rules laid down in the Withdrawal Agreement must be underlined.

The text of the Agreement envisages the possibility of an EU-UK agreement governing their relationship in the area of CFSP, which becomes applicable during the transition period (Art. 127 (2)) ending on 31 December 2020. Such a thematic agreement on one hand may indicate that CFSP is a sensitive political area in which the UK would like not be bound by EU rules as soon as possible - that both the opt-out clause (CFSP) and the derogations on CSDP (PESCO and EU missions and operations) may already confirm; and, on the other hand, cannot be understood and designed outside of the framework and guidelines set out in the Political Declaration regarding foreign policy, security and defence - namely the specific areas of future consultation and cooperation and the mechanisms already identified, which have to constitute a common basis for the future relationship between the EU and the UK in this respect.

Moreover, the two derogations regarding CSDP - PESCO and EU missions and operations - may indicate the will of the UK not to be involved in principle neither in the deepening and the development of the EU security and defence policy nor in assuming leading responsibilities within EU

Policy, indicating that for vital and stated reasons of national policy, in those exceptional cases, it will not apply the decision (and that in a spirit of mutual solidarity, the UK shall refrain from any action likely to conflict with or impede Union action based on that decision and the Member States shall respect the position of the UK). 
missions and operations conducted under Articles 42, 43 and 44 TEU (or operational actions under Article $28 \mathrm{TEU}) .{ }^{73}$ In special, considering that PESCO is a form of enhanced cooperation that is at the core of the recent defence policy developments post EU Global Strategy, the derogation regarding PESCO is in line with the fact that the UK did not sign the Joint Notification on PESCO in November 2017. However, this derogation does not preclude the possibility for the UK to be invited to participate as a third country in individual projects under the conditions set out in Council Decision (CFSP) 2017/2315 74 on an exceptional basis, or in any other form of cooperation to the extent allowed and under the conditions set out by future Union acts adopted on the basis of those Articles 42(6) and 46 $\mathrm{TEU}^{75}$ - the latter still to be determined. Therefore, even if such rules of the Agreement also clearly indicate that the participation of the UK as a third State in PESCO project is admissible by both parties in a longer term perspective, the conditions under which the UK may participate are not yet fully determined. ${ }^{76}$

In addition, and despite the above mentioned derogations, concerning financial support of CFSP/CSDP, the Agreement foresees that until the end of the transition period $(31 / 12 / 2020)$ the UK shall continue to contribute to the financing of the European Defence Agency (and of the EU

73 Art 129 (7) foresees that during the transition period, the UK shall not provide commanders of civilian operations, heads of mission, operation commanders or force commanders for missions or operations conducted under Arts 42, 43 and 44 TEU, nor shall it provide the operational headquarters for such missions or operations or serve as framework nation for Union battlegroups and also that during that period the UK shall not provide the head of any operational actions under Art 28 TEU.

74 Arts 4 (2) (g) and 9 (1) of Council Decision (CFSP) 2017/2315 of 11 December 2017 establishing permanent structured cooperation (PESCO) and determining the list of participating Member States, and Council Recommendation of 6 March 2018 concerning a roadmap for the implementation of PESCO, no 13.

75 Art 127 (7) (a) of the Withdrawal Agreement.

76 According to the Council Conclusions on Security and Defence in the context of the EU Global Strategy (Conclusions of 19 November 2018, 1378/18 of 19 November 2018), no 12, a Council decision on the general conditions under which third States could exceptionally participate was expected to be adopted by the end of 2018. However, the Conclusions already indicate some general rules in this respect: a third State would need to provide substantial added value to the PESCO projects, contribute to strengthening PESCO and the CSDP and meet more demanding commitments, while fully respecting the principle of decisionmaking autonomy of the EU and its Member States. - From the UK perspective see House of Commons, Briefing Paper No 8149, Updated December 2018, EU Defence: the realisation of Permanent Structured Cooperation (PESCO), no 5. 
Institute for Security Studies and the EU Satellite Centre) as well as to the costs of CSDP operations, on the basis of the same contribution key, namely in accordance with its Article $5^{77}$.

Finally, although the Agreement on the Withdrawal of the UK does not ignore the issue of CFSP/CSDP and the role of the UK during the transition period, it does not bring much light on the future EU-UK relationship in that field: not only because none of the terms of the (future) agreement is addressed but also because in the only area in which a future UK participation is foreseen as it was already a third State (PESCO), the rules of such participation are still uncertain since not yet determined by EU secondary law. Therefore, the terms of the EU-UK relationship and possible main issues and forms of cooperation in the fields of CFSP/CSDP after the transitional period are still rather uncertain and do not exclude a differentiated third State status.

\section{B. The Political Declaration and Foreign Policy, security and defence}

However, the Political Declaration setting out the framework for the future relationship between the EU and the UK on 25 November 2018 (foreseen in Article 184 of the Withdrawal Agreement) may, to a certain extent, contribute to clarify the general features of the future EU-UK relationship regarding CFSP/CSDP beyond the transitional period.

Considering its contents on 'Foreign Policy, security and defence', as mentioned above, some of its features are particularly relevant to shape the terms of that future relationship after the end of the transition period. Three of such features should be underlined.

Firstly, the text of the Political Declaration indicates that both parties accept common general grounds for their future relationship based in common core values and rights, identification of areas of shared interests

77 Within the financial provisions of Part Five, Art 156 (The United Kingdom's obligations from the date of entry into force of this agreement) of Chapter 7 (Agencies of the Council and Common and Security Defence Policy operations) foresees as follows: Until 31 December 2020, the United Kingdom shall contribute to the financing of the European Defence Agency, the European Union Institute for Security Studies and the European Union Satellite Centre, as well as to the costs of Common Security and Defence Policy operations on the basis of the same contribution key set out in point (a) of Article 14(9) of the Council Decision (EU) 2016/1353, in Article 10(3) of Council Decision 2014/75/CFSP, in Article 10(3) of Council Decision 2014/401/CFSP and in the second paragraph of Article 41(2) of the TEU, respectively, and in accordance to Article 5 of the Agreement. 
in which participation in Union programmes and dialogues are envisaged. ${ }^{78}$ These common general grounds are subsequently detailed in the text of the Political Declaration regarding each area of the EU-UK future partnership, namely in Part III: Security partnership within which the area of 'Foreign policy, security and defence' is addressed (as mentioned above).

Secondly, within the EU-UK Security Partnership, the guidelines on 'Foreign policy, security and defence' foresee general guidelines and instruments regarding dialogue, consultation, coordination and cooperation in this area: (i) structured consultation and regular thematic dialogues identifying areas and activities where closer cooperation could contribute to the attainment of common objectives, namely the Political Dialogue on CFSP and CSDP as well as sectorial dialogues at different levels (ministerial, senior office, working), including invitation of the UK to informal Ministerial meetings of EU Member States; (ii) seeking to cooperation in third countries (including in security consular provision and protection and development projects) as well as in international organisations and fora, notably the UN, allowing the Parties to support each other's positions, deliver external action and manage global challenges in a coherent manner, included through agreed statements, demarches and shared positions. The latter may implicitly refer to the permanent seat of the UK and France in the UN Security Council and cooperation within that organ but may as well refer to the rules of coordination between Member States in international organisations and conferences, including the Security Council, foreseen in Art. 34 TEU; to the rules on cooperation between the external delegations of the EEAS and the diplomatic and consular missions of the EU Member States laid down in Art. 221, 2 TEU - so that after the end of transition period similar coordination and cooperation may continue. However, the concrete terms of both mentioned consultation and cooperation are not foreseen except for the level of consultation and dialogue, the case by case invitation to the informal Ministerial meetings - and still have to be determined in future agreements to be negotiated and signed on the basis of Article 148 of the Withdrawal Agreement.

Thirdly, CSDP is specifically addressed within the concrete areas where EU-UK cooperation is already envisaged (Part III, III, B. to G.) despite their strategic autonomy and freedom of action. In this respect, three of the areas of CSDP already addressed in the Withdrawal Agreement are also men-

78 See Political Declaration, Part I: Initial provisions, I. Basis for cooperation, A. Core values and rights, 6-7 and II. Areas of shared interests, A. Participation in Union programmes and B. Dialogues, 11-15. 
tioned: EU operations and missions, PESCO, and financing of CSDP projects - either through the UK collaboration on existing and future projects of the EDA or the participation of eligible UK entities in collaborative defence projects bringing together Union entities supported by the EDF.

Regarding PESCO, the Political Declaration merely assumes the UK's collaboration in projects in the framework of PESCO 'where invited to participate on an exceptional basis' by the Council of the EU in PESCO format and no further rules are foreseen (Part III, III, D., 104 (c)).

Concerning EU's missions and operations (Articles 42 (1) and 43 (1) TEU), the Political Declarations foresees close cooperation in EU-led 'crisis management missions and operations' enabling the UK to participate on a case by case basis in CSDP missions and operations - opened to third countries - through a Framework Participation Agreement (FPA). In this respect some specific rules are already laid down (Part III, III, C. 101-103): the UK may indicate its intention to contribute to a planned CSDP mission or operation (open to third countries); in this case the parties should intensify interaction and exchange of information at relevant stages of the planning process and proportionately to the level of the UK's contribution; and as a contributor to a specific CSDP mission or operation the UK would participate in several relevant bodies meeting (Force Generation, Call for Contributions and the Committee of Contributors meeting) and would have the possibility, in case of CSDP military operations, to second staff to the designated Operations Headquarters proportionate to the level of its contribution. This outline for the future UK participation in EU-led crisis management and operations, does not however envisages neither any form of a differentiated statute of the UK (i.e., according to which the UK could be envisaged as more than a third State) nor (apparently) a participation in all possible missions and tasks foreseen in Articles. 42 (1) and 43 (1) TEU since it refers specifically (to 'Union-led crisis management missions and operations' Part III, III, C., par. 101, first sentence) - which are referred to, among other tasks, in Article 43 (1) TEU ('tasks of combat forces in crisis management, including peace-making and post-conflict stabilisation').

From the contents of both the texts of the Withdrawal Agreement and the Political Declaration regarding the area of CFSP/CSDP in particular some general conclusions can be drawn: 1) EU and UK foreign policies (including security and defence areas) are autonomous despite common values and objectives; 2) on the grounds of shared security and defence interests close - 'flexible and scalable' - cooperation may exist; 3) a few general guidelines for consultation and dialogue regarding foreign policy, security 
and defence are foreseen but those still need to be further detailed; 4) some specific areas of close cooperation are already identified, namely sanctions, intelligence exchanges, space and development cooperation; 5) in the concrete field of EU CSDP, the participation of the UK in PESCO projects and in EU-led crisis management missions and operations both civilian and military is admitted to be tough and exceptional, on a case to case basis and apparently in the capacity of a (mere) third State; 6) in the concrete field of defence capabilities development the UK and its eligible entities may collaborate in relevant projects of the EDA through an Administrative Arrangement and in collaborative defence projects supported by the EDF so that both parties may benefit from research and industrial cooperation in order to facilitate inter operability and to promote joint effectiveness of Armed Forces. Those conclusions may indicate that the future EU-UK relationship in the area of CFSP/CSDP, on one hand is rather programmatic and modest and that the concrete terms of the participation are rather narrow and still need to be detailed (in future agreements) and that no specific ex-EU Member State statute is envisaged; and, on the other hand, that some of the concrete areas in which closer cooperation is envisaged (in particular PESCO and defence capabilities development) relate to the sub-area of CSDP in which EU policy post-EU Global Strategy has more quickly evolved.

However, the guidelines laid down in the Withdrawal Agreement and the Political Declaration appears to still leave room to shape a differentiated third State status in the field of CFSP/CSDP. Even in areas where the status of third State is clearly mentioned - PESCO and EU missions and operations - neither the rules of third States participation are definitively defined nor is the envisaged FPA necessarily bound to follow a single model.

\section{Shaping a (possible) differentiated third state status in the field of CFSP, including CSDP}

\section{A. Common grounds as a basis of the future EU-UK relationship}

Addressing the issue of the future of EU's CFSP, including CSDP, after Brexit cannot ignore the possibility of different scenarios, despite the intentions of cooperation of both involved parties - the EU and its Member States on one hand, and the UK as a (future) third State on the other side -, including a more radical scenario in which the UK, once having left the EU, would simply be treated as another third State that would only be able 
to participate in the EU's CFSP and CSDP to the extent that the EU allows it and under the model and forms of participation that already exists today regarding current third States. This scenario would mean basically none or very weak involvement in the EU's CFSP and CSDP decision-making process and implementation of such policies - even if the EU would have to relate to the UK as an autonomous international actor within several formal international organisations and informal groups participating in the global governance in the area (or related-areas) in question. However, and being the first time that Article 50 clause is activated, it is arguable that in the particular areas of CFSP and CSDP a stronger link between the EU and its Member States and the UK may (and should) exist - although in terms that are not yet completely clear. In fact, the EU's CFSP and CSDP can undoubtedly proceed in its current course based on the EU Global Strategy and the defined 'three pillars' strategy without the UK, but it is questionable that it would be advisable to do so. And if that is not the case, common grounds for a future (different) relationship should exist.

Considering the contents of both the texts of the Withdrawal Agreement (Article 184) and the Political Declaration it can be assumed that such common grounds for the EU-UK future relationship in the field of CFSP/CSDP do exist, despite possible divergent views regarding strategic interests and specific issues. These common grounds can be found either in the axiological basis of the European integration (democracy, rule of law and fundamental rights values) as well as in the UN values and principles, or in shared objectives or shared need to address common threats and increasing challenges to European foreign policy, security and defence - especially those that a single State or States in a bilateral relationship are not able to cope with. Such common grounds can concretely be found, as mentioned above, in the Political Declaration where common values and shared objectives, are foreseen ${ }^{79}$. These shared objectives in respect of foreign policy, security and defence can be listed as follows (as enounced in Part III, III, pars. 92-95): protect citizens from external threats, prevent conflicts, strengthen international peace and security, including through the UN and NATO; address the root causes of global challenges such as terrorism or illegal migration, champion a rules-based international order and project (their) common values worldwide; promote sustainable devel-

79 See Part I: Initial Provisions, I. Basis for cooperation, A. Core values and rights and II. Areas of shared interest and in particular Part III: Security Partnership, I. Objectives and principles (80-81) and III. Foreign policy, security and defence (92-93). 
opment and the eradication of poverty and support the implementation of the UN Sustainable Development Goals and the European Consensus on Development. The shared objectives are in line with the EU CFSP objectives foreseen in the TEU as well as with the broad priorities established by the EU Global Strategy.

Moreover, even if autonomous EU and UK foreign policies and therefore different approaches and strategic and security interests (either by geographical, historical or political reasons) may (and do) exist, cross-spheres of interest and activities may still be of interest for both parties allowing each other to act on specific issues and matters but contributing to the overall relevance of Europe within international scene. The Political Declaration indicates that current areas of shared interests are already identified (sanctions, operations and missions, defence capabilities development, intelligence exchanges, space and development cooperation) and new areas of shared interests and close cooperation may be identified in order to attain common objectives, namely through structured consultation and thematic dialogues.

In the field of CFSP and in particular in the field of CSDP the role and contribution of the UK to the implementation of EU objectives up to the present cannot be ignored, either because of its capabilities or different forms of contribution, namely financial (mainly through the EU budget), to the CSDP.

However the way in which the EU will deal with the UK desire to participate, to some extent, in the field of CFSP and CSDP also depends on the development of the implementation of the Global Strategy, the EU new level of ambition and an eventual future decision on a common defence policy (more autonomy vs deeper collaboration with relevant partners in key areas, such as NATO) - and where is the razor's edge in both the perspective of the EU and UK (vg no common defence policy and European army).

In the scenario in which the UK would be a third State, a close relationship with the EU would still be possible by shaping a differentiated third State status in the field of CFSP, including CSDP. 


\section{B. Possible issues and forms of cooperation to be addressed}

The consideration of the wider context, the EU trends, concerns expressed on both $\operatorname{sides}^{80}$ and doctrine proposals ${ }^{81}$ allow to identify a wide range of both, political and juridical issues regarding the post Brexit and post transitional period future relationship between the EU and the UK, specifically in the field of CFSP and CDSP.

Some of those issues, although not foreseen in the Withdrawal Agreement, were further addressed in general terms and partially clarified in the Political Declaration on 25 November 2018. According to that text: foreign policy, security and defence are addressed together, as a part of a EU-UK security partnership, based on common objectives; the UK may collaborate to some extent in CFSP and CSDP; no other status than the status of third State is expressly envisaged, in particular in respect of the participation of the UK in EU missions and operations and PESCO projects; the envisaged collaboration reveals - besides general structured consultation and thematic consultation - a selective thematic approach in six identified areas; participation of the UK in decision making and EU institutions and organs is only foreseen to the extent that the UK can be invited by the High Representative to informal Ministerial meetings (defence) and may participate in certain EU missions and operations (crisis management) and therefore in their respective structures and organs, although in proportion to the level of its contribution; the mechanisms foreseen to ensure the EU-UK relation-

80 See also House of Lords European Union Committee, Europe in the World: Towards a More Effective EU Foreign and Security Strategy, 16 February 2016, HL paper 97 of session 2015-16; House of Lords Commons Affairs Committee, Implications of the Referendum on EU membership for the UK's Role in the World, 26 April 2016, HL 545 session 2015-16.

81 See M Chalmers, 'UK Foreign and Security Policy after Brexit' (2017), RUSI Briefing Paper, January 2017; H Dijkstra, 'UK and EU Foreign Policy Cooperation after Brexit' (2016), RUSI Newsbrief, 5 September 2016; N Witney, 'Brexit and Defence: Time to Dust Off the 'Letter of Intent'?' (2016), European Council of Foreign Relations, 14 July 2016; S Peers, 'The EU's New Defence Plans Don't Amount to an Army - So the UK Can't Veto Them' (2016), London School of Economics and Political Science Brexit Blog, 28 September 2016; I Bond, 'Brexit and Foreign Policy: Divorce? (2016), Centre for European Reform, 18 July 2016; G Van der Loo and S Blockmans, 'The Impact of Brexit on the EU's International Agreements', 15 July 2016 (available at www.ceps.eu); C Major and A von Voss, 'European Defence in View of Brexit', SWP Comments 2017/C 10, April 2017, 4 p (available at swp-berlin.org); as well as James Black et al., Defence and Security after Brexit. Understanding the possible implications of the UK's Decision to Leave the EU, Compendium Report (Cambridge, Rand Europe, 2017, available at www.rand.org). 
ship and the model of (closer) cooperation regarding EU missions and operations (Framework Participation Agreement) and EDA (Administrative Arrangement), are not innovative since collaboration with third States through those instruments already exist; ${ }^{82}$ participation in international organisations and international bodies is foreseen in terms of consultation, coordination and mutual support of each other's positions in such fora; financial participation of the UK seems to be rather weak and relates mainly to the financing of EU-led missions and operations as well as PESCO projects.

It is therefore now certain that certain forms of cooperation between the EU and the UK in the field of CFSP/CSDP after the end of the transition period have already been addressed in general terms by the Political Declaration as mentioned above - namely common objectives, general provisions of consultation and cooperation in order to achieve them, areas of (current) shared interests and instruments (dialogue, consultation, coordination, exchange of information and cooperation mechanisms).

However, those terms must still be further detailed in the text of the treaty that will apply to the EU-UK relationship after the transitional period in order to translate such general guidance rules into more concrete ways of EU-UK collaboration in the area of CFSP/CSDP (especially when the guidelines are not detailed,vg Space and Development cooperation).

This next step - negotiating and agreeing on more detailed rules - appears to be an opportunity to envisage the features of a possible differentiated third State status in the field of CFSP/CSDP.

In this respect, three points should be underlined in particular that may require further reflection from both involved parties.

First, detailed rules still have to be negotiated and agreed between both parties regarding the points addressed in the Declaration in general terms, which is especially the case of the consultation and cooperation and the establishment of a structured consultation and regular thematic dialogues which seems to be the main instrument for EU-UK consultation and coop-

82 The participation of third States in EU operations was institutionalized through the signing of FPA since 2004 (see Thierry Tardy, CSDP: getting third States on board, EU Institute for Security Studies, Brief Issue, 6, 2014 (available in www.iss. europa.eu) - vg Framework Agreement between the United States of America (USA) and the EU on the participation of the USA in EU crisis management operations, [2011] OJ 1143/2. Administrative Arrangements have already been concluded with third States - Norway (2006), Switzerland (2012) Republic of Serbia (2013) and Ukraine (2015) - enabling them to participate in EDA's projects and programs (see www.eda.europa.eu). 
eration in foreign policy and security. It is not yet quite clear whether the mentioned closer cooperation will rely completely on a flexible and scalable cooperation built on a mere case by case approach, according to their strategic and security interests eventually shared at a certain time, or whether both parties want to build a medium and long term stronger partnership based on a continuous and effective cooperation on common grounds enabling them to act together in foreign policy issues. The translation of the general prevision of the Political Declaration regarding the future structured consultation and thematic dialogue into more concrete procedures and rules (as vg those proposed in the DExEU Policy paper of 24 May 2018 above mentioned in II., B.) may be the opportunity to design a status of UK that may clearly differ from the current status of a mere third State. Also in this respect, the shaping of the concrete rules regarding structured and thematic dialogue may lead to the regular contribution of the UK if not to decision making (which is not probable since autonomy of both parties is also foreseen) at least, to some extent, to decision shaping in those topics of clear shared interest where a collective response to external threats and problems is more effective (vg sanctions policy as an instrument of CFSP or crisis management). This could be achieved by the regular (or even permanent) presence of UK representatives in EU EEAS and in particular CFSP structures, such as the EUMS and crisis management structures, or even on some EU delegations in third States. Moreover, the consultation and cooperation at bilateral level and within international organisations could be further elaborated in order to envisage the alignment of the UK with EU foreign policy positions and the possible establishment of procedures to adopt in that respect to ensure coordination of positions on a regular basis and even an actio pro communitate.

Second, and in particular in respect of PCSD, one may question why the EU and the UK have not gone further and tried to envisage and design a different status for the UK, 'half-way' between a full EU Member State and a mere third Member State - even if such approach depends on the political will of both parties. However weak the UK contribution (financial or in civil and military capacity) to the CFSP/CSDP may be, and even recognising the lack of consensus on some foreign policy topics, a relationship of decades as an EU 'insider', who participates in most of the postGlobal Strategy developments, should not be completely thrown away. In this respect, some more detailed guidelines are foreseen in two of the (current) areas of shared interests: EU missions and operations and defence capabilities development, including PESCO. However, such guidelines included in the Political Declaration must still be further detailed - in particular in the text of the treaty that will apply to the EU-UK relationship after 
the transitional period. Moreover, further formal agreements - such as the mentioned Framework Participation Agreement regarding EU CSDP missions and operations or Administrative arrangement regarding the participation in the EDA - as well as secondary EU law rules - at least regarding the requisites of participation in PESCO projects - still have to be, respectively, agreed upon by both parties and approved, as a sine qua non condition of a concrete and effective collaboration between the EU and the UK beyond the term of the transitional period (31 December 2020) foreseen in the Withdrawal Agreement. In this respect, the elaboration on the concrete terms of such agreements (old instruments with new contents) and of secondary rules regarding the participation of third States in PESCO projects will be an opportunity to further deepen the terms of the future relationship foreseen in the Political Declaration and maybe not (completely) close the door to the possibility of having a different status and model of cooperation (more and differentiated rights of participation in CFSP and more financial and other duties), regarding the participation of a (not mere, since ex-Member State) third State.

Finally, the possible differentiated third State status on a basis that overcomes a simply case by case cooperation (vg on thematic block or even geographical approach basis) could also be achieved - if the political will allows - through the agreement on a formal (or informal) observer status, with some rights of participation in EU institutions, bodies and structures (decision shaping) with financial EU counterparty ('value for money') that could be agreed namely through a contribution to the financing of the most relevant CFSP financial instruments besides the EU budget. 
